DOI: 10.38136/jgon.737139

\title{
Kalp hastalığı olan gebelerin retrospektif analizi
}

\section{Retrospective analysis of pregnancies with heart disease}

\author{
Erkan ELÇi \\ Harun Egemen TOLUNAY ${ }^{2}$
}

(1) Orcid ID:0000-0002-9792-6592

(1) Orcid ID:0000-0002-8922-4400

${ }^{1}$ University of Health Umraniye Traning and Research Hospital Department of Obstetrics and Gynecology, Istanbul, Turkey
${ }^{2}$ Etlik Zübeyde hanım Maternity and Women's Health Teaching and Research Hospital, Department of Perinatology, Ankara, Turkey

\section{Öz}

Amaç: Bu çalışmada, gebelik öncesi veya gebelik sırasında ekokardiyogramdan kalp hastalığı tanısı konan gebelerin demografik özellikleri, eşlik eden kalp hastalığı ve doğum şekli retrospektif olarak incelendi.

Gereçler ve yöntem: Çalışmamıza 2009-2014 döneminde Van eğitim ve araştırma hastanemize başvuran gebeler dahil edildi. Doğum yapan kadınların kayıtları geriye dönük olarak tarandı.

Bulgular: Hamilelikten önce veya gebelik sırasında ekokardiyogram ile tanısı konan hastalar, kalp hastalığı olan hamile kadınlar olarak kabul edildi. Dekompresyonlu kalp hastalıkları nedeniyle gebeliği sonlandırılan hastalar çalışma dışı bırakıldı. 37520 doğum yapan gebe incelendi. Kalp hastalığı olan komplike gebeliklerin sayısı 132 (\% 0.35), bu hastaların 45'inde sezaryen (C/S) yapıldı. Mitral kalp kapak hastalıkları, gebelerde kalp hastalığının en sık sebebi olarak bulundu. Gebeliği zorlaştıran kalp hastalığı, ileri anne yaşı ile birlikte arttığını görüldü.

Sonuç: Hamilelikteki fizyolojik değişiklikleri ve bunların belirli kalp rahatsızlıkları üzerindeki etkilerini anlamak, hamilelik sırasında yönetimin temelini oluşturur. Bu kadınlar için yakın gözetim önerilmelidir. Gebelikten önce, hastalar kardiyovasküler bir değerlendirme ve danışmanlık almalı ve bu birincil amaç olmalıdır.

Anahtar Kelimeler: Gebelik, Kalp hastalığı, kalp hastalığı olan hamile kadınlar, gebelikte kalp hastalığı, gebelik analizi

\section{INTRODUCTION}

Hypercoaguability, decreased systemic vascular resistance, increased intravascular volume and cardiac output occur during pregnancy. These changes may cause symptoms to exacerbate in pregnant women with heart disease. $0.2-4 \%$ of

\section{ABSTRACT}

Aim: Pregnant women who were diagnosed with a cardiac disease, with an echocardiogram before or during pregnancy, were retrospectively analysed according to sociodemographic characteristics, causes of heart disease and the way of birth in this study.

Materials and Methods: Pregnant women who delivered at our training and research hospital in the time period of 2009-2014 were included in this study. The records of women who gave birth were screened retrospectively.

Results: Patients who were diagnosed with an echocardiogram before or during pregnancy were considered as pregnant women with heart diseases. Patients who underwent pregnancy termination due to decompressed heart diseases were excluded from the study. 37520 deliveries were examined. The number of complicated pregnancies with heart disease was $132(0.35 \%)$, 45 of these patients had a caesarian section (C/S). Mitral valve diseases were found to be the most common cause of heart disease. Heart disease complicating pregnancy is increasing with advanced maternal age.

Conclusion: Understanding the physiological changes in pregnancy and their effect on specific cardiac conditions forms the basis of management during pregnancy. Close surveillance should be offered for these women. Prior to pregnancy, patients should receive a cardiovascular assessment and counseling, this should be a primary goal.

Key Words: Pregnancy, Heart disease, pregnant women with heart disease, cardiac disease in pregnancy, analysis of pregnancies

all pregnancies are accompanied by cardiovascular diseases (1). Heart diseases are amongst the most important causes of maternal morbidity and mortality in pregnancy. Pregnant women with heart disease are at a high righer risk for cardiovascular complications, neonatal complications and even 
maternal death (2). Favourable outcomes are obtained when pregnant patients with heart disease follow a careful follow-up, taking into consideration maternal and fetal risks (3). In this study we retrospectively analyzed pregnant women who had complications due to a cardiac disease.

\section{MATERIAL AND METHOD}

Pregnant women who delivered in Van Training and Research Hospital between 2009-2014 were included in the study. The records of women who gave birth were screened retrospectively. Patients who were diagnosed with a echocardiogram before or during pregnancy were considered as pregnant women with a heart disease. Patients who underwent pregnancy termination due to decompressed heart disease were excluded from the study. All pregnant women were given prophylactic antibiotics during delivery. Demographic characteristics of the patients, echocardiographic findings of heart diseases, cesarean indications and obstetric outcomes were evaluated. The study was approved by the local ethics committee of the Yüzüncü Yil University Faculty of Medicine Department in Van (YYUTF-190614-04).

\section{RESULTS}

The total number of deliveries examined was 37520 . The number of complicated pregnancies with a heart disease was 132 $(0.35 \%)$. The mean age of the patients was $30.1 \pm 6.24$ and the mean parity was $3.3 \pm 2.9$. The mean gestational week was $37.3 \pm 4.1 .52 \%$ of the patients were uneducated and $6,1 \%$ patients were diagnosed with a heart disease before pregnancy. The sociodemographic characteristics of pregnancies complicated by heart disease are shown in Table-1.

Table 1: Sociodemographic characteristics of pregnancies complicated by heart disease

\begin{tabular}{ll}
\hline Age & $30.1 \pm 6.24$ \\
Mean \pm SD & $5.1 \pm 3.1$ \\
\hline Number of pregnancy & $3.3 \pm 2.9$ \\
Mean \pm SD & \\
\hline Number of births & $0.3 \pm 0.8$ \\
Mean \pm SD & \\
\hline Number of aborts & $37.3 \pm 4.1$ \\
Mean \pm SD & \\
Delivery Week & \\
Mean \pm SD
\end{tabular}

Mitral valve diseases were found to be the most common cause of heart disease: 52 patients had mitral valve insufficiency and 36 had mitral valve stenosis. These were followed by atrial septal defect (ASD), aortic valve insufficiency, aortic stenosis, tricuspid valve failure and dilated cardiomyopathy (Table-2).

Table 2: Causes of heart disease in pregnant women with heart disease

\begin{tabular}{|c|c|c|c|}
\hline & & $\mathrm{n}$ & $\%$ \\
\hline $\begin{array}{l}\text { Total pregnant } \\
\text { woman }\end{array}$ & & 37520 & 100 \\
\hline $\begin{array}{l}\text { Pregnant wo- } \\
\text { men with heart } \\
\text { disease }\end{array}$ & & 132 & 0,35 \\
\hline & Mitral valve insufficiency & 52 & 39,3 \\
\hline & Mitral valve stenosis & 36 & 27,2 \\
\hline & Atrial Septal Defect & 20 & 15,1 \\
\hline & Aortic valve insufficiency & 10 & 7,5 \\
\hline & Aortic valve stenosis & 9 & 6,8 \\
\hline & Tricuspid valve insufficiency & 3 & 2,2 \\
\hline & Dilated Cardiomyopathy & 2 & 1,5 \\
\hline
\end{tabular}

45 of the patients had caesarean sections. Caesarean indications were mostly detected as cephalopelvic disproportion (CPD) and presentation abnormality (CPD;14, presentation abnormality;12). Other indications for $\mathrm{C} / \mathrm{S}$, were fetal distress and preterm delivery (Table 3 ).

Table 3: Causes of cesarean section in pregnant women with heart disease

\begin{tabular}{lll}
\hline & $\mathrm{n}$ & $\%$ \\
\hline Cephalopelvic disproportion & 14 & 31,1 \\
\hline Malpresentation & 12 & 26,6 \\
\hline Previous C/S & 11 & 24,5 \\
\hline Fetal distress & 5 & 11,1 \\
\hline Preterm birth & 3 & 6,7 \\
\hline Total & 45 & 100 \\
\hline
\end{tabular}

Newborn results revealed a 1 minute Apgar score of $7.20 \pm 2.15$ and a 5 minute Apgar score of $8.60 \pm 1.35$. Neonatal mortality was not detected.

\section{DISCUSSION}

Cardiac disease (CD) is a leading cause of ICU admission in the obstetric population. In the United States, cardiovascular diseases are the leading cause of maternal death, causing $4.23 \mathrm{de}$ aths in 100,000 live births in postpartum and pregnant women (4). The most recent data shows that cardiovascular diseases are responsible for $26.5 \%$ of pregnancy-related deaths in the United States (4)

According to the literature cardiac diseases complicate $1-4 \%$ of pregnancies $(5,6)$. This rate was found in $0,35 \%$ of our cases. Cardiac diseases can either be acquired or congenital. Women with congenital heart disease are at risk for adverse outcomes during pregnancy (7). If the mother has a congenital heart defect, it is risk for the fetus. Fetal echocardiography is also re- 
commended for these pregnancies. In our cases, no baby had a congenital heart disease. Maternal mortality rate in pregnant women with heart disease is seen to be up to $12 \%$ (8). One death was seen in our study, her case was complicated by dilated cardiomyopathy.

Antibiotics are recommended only for patients who are deemed to be at a high risk for infective endocarditis (IE) (9). The Incidence of IE is $3-10 \%$ in pregnancy, similar to the analysis for general population (10). The most common risk factors for IE in pregnancy are drug interventions (14-43\%) and congenital heart diseases (12-38\%) (10). In our study, all women were found to be on antibiotic prophylaxis during delivery. Pregnancies with cardiac disease should be managed by a multidisiplinary team of specialists including obstetricians, cardiologists and anesthesiologists (4). A cardiac echocardiogram should be performed for all pregnants in the antenatal period. Antepartum activity restriction, treating coexisting medical conditions, epidural anesthesia during delivery and help avoiding hypovolaemia should be provided $(11,12)$. Operative deliveries in pregnant women with heart disease are associated with an increased morbidity such as blood loss and a thromboembolism risk.

Vaginal birth is generally preferred for the way of birth in women with $\mathrm{CD}$. Caesarean delivery is recommended only in the presence of obstetric indications in these patients according to the European Society of Cardiology (ESC) guidelines (11, $12,13)$. Cesarean sections were also performed with obstetric indications in our patient group (45\%), our most common indication was CPD.

Women with mechanical heart valves are at an increased risk of adverse pregnancy outcomes including valve thrombosis, hemorrhage and death. These women need to be therapeutically anticoagulated throughout pregnancy and the postpartum period (although optimal anticoagulation during pregnancy is still controversial) (14). In our cases mechanical valve replacement was not reported.

\section{CONCLUSION}

There are currently many medical and surgical advances. Heart disease complicating pregnancy is increasing with advanced maternal age. Understanding the physiological changes of pregnancy and their effects on specific cardiac conditions forms the basis of management during pregnancy. Prior to pregnancy, cardiovascular assessments and counseling should be a primary goal. Heightened awareness to optimize cardiac status, close perinatal surveillance and a coordinated management team are critical to improve maternal and fetal outcome.

\section{Acknowledgements}

The authors gratefully acknowledge Dr.Numan ÇiM (Department of Obstetric and Gynaecology,Istanbul Bilim University Medical Faculty) for him advice

Declaration of interest

The authors report no declarations of interest. The authors alone are responsible for the content and writing of the paper

\section{REFERENCES}

1 Endorsed by the European Society of Gynecology tAfEPC, Medicine tGSfG, Members ATF, Regitz-Zagrosek V, Blomstrom Lundqvist $C$, Borghi $C$, et al. ESC Guidelines on the management of cardiovascular diseases during pregnancy: the Task Force on the Management of Cardiovascular Diseases during Pregnancy of the European Society of Cardiology (ESC). European heart journal. 2011;32(24):3147-97.

2 Arafeh JM, Baird SM. Cardiac disease in pregnancy. Critical care nursing quarterly. 2006;29(1):32-52.

3 Berg CJ, Callaghan WM, Syverson C, Henderson Z. Pregnancy-related mortality in the United States, 1998 to 2005. Obstetrics \& Gynecology. 2010;116(6):1302-9.

4 ACOG Practice Bulletin No. 212 Summary: Pregnancy and Heart Disease, Obstetrics \& Gynecology, 2019, 133 (5); 1067-1072

5 Merck GW. Pregnancy complicated by disease. In: The Merck manual of diagnosis and therapy. No 18. New Jersey: Merck and Co, 2001; 1-3.

6 Small MJ, James AH, Kershaw T, Thames B, Gunatilake R, Brown H. Near-miss maternal mortality: cardiac dysfunction as the principal cause of obstetric intensive care unit admissions. Obstetrics \& Gynecology. 2012;119(2):250-5.

7 Steiner, Jill MD, MS; Lokken, Erica PhD, MS; Buber, Yonatan MD; Albright, Catherine MD, MS Obstetric and Cardiac Outcomes of Pregnant Women With Congenital Heart Disease by Functional Class [25N], Obstetrics \& Gynecology, 2020; 135: 152.

8 Ford AA, Wylie BJ, Waksmonski CA, Simpson LL. Maternal congenital cardiac disease: outcomes of pregnancy in a single tertiary care center. Obstetrics \& Gynecology. 2008;112(4):828-33.

9 Obstetricians ACo, Gynecologists. ACOG Practice Bulletin No. 120: Use of prophylactic antibiotics in labor and delivery. Obstetrics and gynecology. 2011;117(6):1472.

Lal, Ann K., and Thaddeus P. Waters. "Endocarditis 
in Pregnancy." Cardio-Obstetrics: A Practical Guide to Care for Pregnant Cardiac Patients, 2020, 1 (18); 169

11 Spooner SF. High Risk Pregnancy: Management Options 3rd edition. The Obstetrician \& Gynaecologist. 2007;9(3):211-.

12 Siu SC, Sermer M, Colman JM, Alvarez AN, Mercier L-A, Morton BC, et al. Prospective multicenter study of pregnancy outcomes in women with heart disease. Circulation. 2001;104(5):515-21.

13 Petrus, A. H. J., Jongert, B. L., Kiès, P., Sueters, M., Jongbloed, M. R. M., Vliegen, et. al. Evaluation of mode of birth in pregnant women with heart disease. European Journal of Obstetrics \& Gynecology and Reproductive Biology. 2020;
248;150-155,

14 Rohan D'Souza, Jackie Ostro, Prakesh S. Shah, Candice K. Silversides, Ann Malinowski, Kellie E. Murphy, Mathew Sermer, Nadine Shehata, Anticoagulation for pregnant women with mechanical heart valves: a systematic review and meta-analysis, European Heart Journal,2017;38(19);1509-1516 